\title{
Thinking with John Locke about the nature of human rights: vietnamese and global perspectives
}

\author{
Hoa Thi Kim Do - Michal Valco
}

DOI: 10.18355/XL.2021.14.03.01

\begin{abstract}
Our paper explores important topics related to John Locke's thoughts on human rights and their viability for our contemporary discourse on the subject. We begin by exploring Locke's education and epistemological reflections as factors that influenced his political philosophy. Next, we examine Locke's views on the 'state of nature,' 'law of nature,' and 'natural rights' and show how his ideas have recently been appropriated (or contested) by Vietnamese and Western scholars. In the final section, we offer a critical assessment of the viability for the contemporary discourse of Locke's metaphysical presuppositions from which he derives his notions of 'natural rights.'
\end{abstract}

Key words: John Locke, human rights, natural rights, state of nature, Vietnamese society

\section{Introduction}

In the course of the development of social and political thought, John Locke (16321704) emerged as an insightful philosopher and politician. His ideas brought about an important turning point, contributing to the Enlightenment period by outlining new themes and trends in political philosophy relevant to the topic of human rights. Many of those who reflected on his ideas became famous and essential figures in the political and social life of their societies, like Charles-Louis de Secondat de Montesquieu (1689-1755), Jean-Jacques Rousseau (1712-1778), or Francois-Marie Arouet Voltaire (1694-1778) to name but a few. Locke's intellectual legacy provided new approaches to the subject, which differed from previous thinkers, such as Niccolo Machiavelli (1469-1527), Richard Hooker (1554-1600), or Thomas Hobbes (15851679). His influence has not been confined to European countries only but has also spread to the United States, becoming foundational for developing a theory of rights and governance principles in the late $1600 \mathrm{~s}$ and the $18^{\text {th }}$ century. Some scholars point out similarities between John Locke and Karl Marx (1818-1883), comparing their ideas and researching their overlaps (Birdal, 2007; Dehaibi, 2015; Rupert, 2017; Gronow, 2016); others are more critical, emphasizing the differences and/or Marx's deviations from Locke's original ideas (Breakey, 2017; Glawson, 2018; Mossoff, 2012). We wish to join in this endeavor and continue exploring important topics related to John Locke's thoughts on human rights and its viability (if nothing else, then as an inspiration) for our contemporary discourse on the subject. We will begin by exploring Locke's education and epistemological reflections as factors that influenced his political philosophy. We will then examine Locke's views on the state of nature, law of nature, and natural rights and show how his ideas have recently been appropriated (or contested) by Vietnamese and Western scholars.

\section{Education and Epistemology as Factors that Influenced Locke's Political Philosophy}

Locke's education at Westminster School in London and later at Christ Church College, Oxford University, helped him focus on nature instead of the books by medieval and ancient authors. He quickly came to appreciate Francis Bacon's (15611626) emphasis on empirical experiments, data collection, and inductive reasoning -

XLinguae, Volume 14 Issue 3, June 2021, ISSN 1337-8384, eISSN 2453-711X 
which constituted the core methodology of the emerging English Royal Society. Locke had thus become enamored by what was then labeled 'experimental philosophy.'

In his An Essay Concerning Human Understanding (1689), Locke demarcated the limits of human reason in acts of knowing, linking human knowledge to empirical experience as its source, though allowing rational reflection, including abstract inferences, based on experience. This put him at odds with earlier approaches to epistemology and learning, namely the Aristotelian, scholastic, and to some extent also the Cartesian approach. Locke's argued against "extending [human] Enquiries beyond their Capacities, and letting their Thoughts wander into those depths where they can find no sure Footing." (Locke, 1975: I.1.7) When it comes to the process of knowing, Locke stands on the empiricists' side. He distinguishes between two types of experiences: (a) sensation (outer stimuli received through senses) and (b) reflection (the intellectual capacity of reason). The human being as a person is conscious of the mental processes nascent to one's brain and is able to reflect on them. Reflection and sensation are two complementary ways of knowing, but the original knowledge comes through sense experience, which is then classified and ordered by the human intellect. Such acts of knowledge are not self-serving, however. Besides their edifying function, their purpose is to enhance human understanding of the surrounding world and, subsequently, improve humans' ability to adapt and improve the human condition. Human ideas verbalized in language, inadequate as they may be, play an important role in this process. Scientific knowledge (in Locke's age, this would be 'natural philosophy') reflects critically on the established ideas about the nature of things and helps converge the nominal essence (i.e., human preliminary ideas expressed in language) on the real essence (true nature of the material world). Such an optimistic epistemological outlook prompts Locke to believe that the human thinking subject can actually know substances even if imperfections and obscurities taint his/her ideas of them. Locke distinguishes 'modes' from 'substances' to make room for 'complex ideas' that order substances in the human mind to facilitate higher comprehension. (Locke, 1975: II.12.4)

These distinctions are important for our further deliberation on the nature of human rights (as conceived of by Locke), as "modes give us the ideas of mathematics, of morality, religion and politics and indeed of human conventions in general." (Uzgalis, 2019: https://plato.stanford.edu/archives/spr2019/entries/locke/) As complex ideas that are built on the cumulative human experience over generations, modes provide standards for definitions of things and phenomena. "Since these modal ideas are not only made by us but serve as standards that things in the world either fit or do not fit and thus belong or do not belong to that sort, ideas of modes are clear and distinct, adequate and complete. Thus in modes, we get the real and nominal essences combined." (Uzgalis, 2019: https://plato.stanford.edu/archives/spr2019/entries/locke/) Modal definitions of social and political realities such as war or slavery (or states of nature in general) provided by Locke in his Second Treatise of Government (Locke, 2003) thus constitute an adequate basis for further deliberation and deduction of consequences, although not without simultaneous experience. Interestingly, Locke considers human knowledge of external objects as only probabilistic and thus inferior to human knowledge of oneself, moral principles, mathematics, or God. However, such 'higher knowledge' must not be reduced to a kind of enthusiastic 'inward persuasion' devoid of reason, lest we fall into delusions.

To achieve moral and intellectual maturity, it is important to direct intentional attention to inculcating personal and civic virtues in humans, starting early on in their upbringing. Locke focuses especially on virtues such as humanity, civility, respect for the rights of others, industriousness, self-denial, courage, sensitivity to prejudices (including one's own), or a sense of justice. Freedom, morality, and reason are closely linked, according to Locke. Before achieving a true state of liberty, therefore, citizens 
must first be educated to think critically, impartially, and without undue modes of passion (which tends to be blind). Reason must be well-informed and morally cultivated in order for the self-government of the people to be successful. Passion, intolerance, and partisanship are the biggest enemies of reason and, therefore, also of successful self-government.

\section{Locke's Contributions to the Englightenment Debate on the 'Natural State' of Humans and 'Natural Rights'}

To truly appreciate Locke's contribution to political and moral philosophy, one should reflect on his ideas against the background of medieval feudal thinking as it had been propagated in $17^{\text {th }}$ century England by Sir Robert Filmer (1588-1653). In summary, Filmer helped to solidify what might be labeled a 'slave paradigm' when it came to the question of political authority and obedience (Cuttica, 2016). According to his doctrine of the divine right of Kings, it is neither natural nor logical to oppose the divinely instituted rule and authority of the King. Humans are born as 'naturally unfree,' i.e., as subjects/slaves who must obey the legitimate ruler. ${ }^{1}$ Filmer derives such paradigm from a faulty exegetical reading of the Bible, claiming that Kings are direct descendants of Adam in their capacity and authority to 'rule the earth' (Daly, 2017), which meant that any opposition to them would have been blasphemous. Kings wield absolute power over their subjects.

Locke rejects such reading of the Bible and refutes Filmer's theory of the origin of political power on the grounds of faulty exegesis and hermeneutics. The reality of excessive force and violence that accompanies the rule of most of the monarchs suggests, according to Locke, that their government is based on brute force rather than divine appointment. (Locke, 2003: II,1,4) To counter this unsatisfactory explanation, Locke developed and employed two theories that had, in various forms, existed in his day and age - (1) a natural rights theory and (2) a social contract theory. Foundational for Locke's thinking was his idea of the existence of a 'natural law' or a 'law of nature.' Aligning one's conduct and the existing socio-political structures with the principles of natural law as expressed in natural rights intrinsic to all humans, according to Locke, constituted the unavoidable foundation for creating social stability, in which human rights, life rights, rights of freedom, property rights, equality and the pursuit of happiness are basic factors to ensure the development of society. For Locke, the most foundational natural right of every human being was the right to fend for one's survival, which includes the right to concrete means that will secure one's survival. What follows is Locke's description of the state of nature and its implications:

"The state of nature has a law of nature to govern it, which obliges every one: and reason, which is that law, teaches all mankind, who will but consult it, that being all equal and independent, no one ought to harm another in his life, health, liberty, or possessions: for men being all the workmanship of one omnipotent and infinitely wise Maker; all the servants of one sovereign Master, sent into the world by his order, and about his business; they are his property, whose workmanship they are, made to last during his, not another's pleasure: and being furnished with like faculties, sharing all in one community of nature, there cannot be

\footnotetext{
${ }^{1}$ We must point out here that Locke entertained the idea of a 'legitimate slavery.' As opposed to 'illegitimate slavery' - when someone possesses absolute power over someone else without just cause - the state of 'legitimate slavery' may arise as the result of victory in battle against an oppressive enemy. For Locke's concept of a 'just war,' see: (Moseley, 2005).
}

XLinguae, Volume 14 Issue 3, June 2021, ISSN 1337-8384, eISSN 2453-711X 
supposed any such subordination among us that may authorize us to destroy another, as if we were made for one another's uses, as the inferior ranks of creatures are for ours. Every one, as he is bound to preserve himself, and not to quit his station wilfully, so by the like reason, when his own preservation comes not in competition, ought he, as much as he can, to preserve the rest of mankind, and may not, unless it be to do justice to an offender, take away or impair the life, or what tends to the preservation of life, the liberty, health, limb, or goods of another." (Locke, 2003: II.2.6)

Humans are the property of their Creator, God. Their actions and socio-political interactions are thus necessarily to be governed by the divine purpose revealed in His glorious works of creation - the natural law (in Locke's words, law of nature). The law of nature concept is essential to Locke's concept of the natural rights of humans. This law of nature reveals the order and principles of an ordered creation. As humans are also an intricate part of creation, their faculty of reason is able to perceive and understand the law of nature. To summarize, Locke's premise is that humans live in a divinely ordered creation, with their primary purpose being to survive. Another premise is that all humans are created equal to live as free human agents in the world. Such premises lead Locke to postulate the four fundamental natural rights of all humans: the right to (1) life, (2) liberty, (3) health, (4) possessions - as all of these are instrumental for human survival. Moreover, the human task of self-preservation is coupled with the task to help in the preservation and well-being of others, as this also happens to be conducive to long-term human survival.

The government comes into place as a 'necessary evil,' so to speak, to ensure the safety and survival of the people who decide to give up the free exercise of some of their rights to increase their chance of survival and general well-being. This is how life, liberty, health, and property can be secured as part of fulfilling the God-given purpose to survive. The free sacrifice on the side of the human individuals of an uncurbed exercise of their natural rights is the essence of the 'Social Contract Theory.' Power rests with the individual people and is delegated from the people to government officials for the benefit of the political community. A legitimate exercise of power then arises from this free giving up of some powers to make the community and life in it safer, more stable, and prosperous - i.e., better equipped to survive. ${ }^{2}$

The state government is instituted to promote justice, an essential principle stemming from the human reflection on the law of nature. In contrast, there is no impartial judge to carry out a punishment proportionate to the crime in the state of nature. Here is, again, where the state comes in with its institutions whose purpose is to see that justice is done. For Locke, a reasonable and impartial government is in a better position to administer justice than a passionate, biased victim (or his family/friends). Administering justice from top-down by the heavy hand of the state, as we indicated earlier, is a necessary evil under the condition of a corrupt human society. Locke seemed to have held the view that the introduction of money in the economically more evolved human societies gave rise to inequality, fueled structural as well as personal injustice, and spawned all kinds of tensions. (Locke, 2003: II.5.50) It is not quite clear whether Locke considered such economic development (i.e., the evolvement towards a monetary economy) as an inevitable historical process that in and of itself is value-neutral, or whether he considered it a grave expression of the 'fall from grace' of humans (Tully, 1982). On the one hand, Locke is a realist when he describes the evolution of human communities from those of hunters and gatherers to

\footnotetext{
${ }^{2}$ Locke follows Hobbes in his attempts to define what a legitimate government is in that he first considers the state of nature without a government (Schochet, 1967) and then explores how civil government can help humans progress to an organized and safe society.
} 
those of farmers and builders. Such development seems to inevitably lead to excesses of wealth by some, especially after the introduction of money in human societies. Also important is for us to notice that the right to property (or: the right to possessions) is, in Locke's view, one of the fundamental, natural rights of humans. Hence there seems to be tension in Locke's concept of the right to property. The following sentences from his Some Thoughts Concerning Education; and The Conduct of the Understanding reveal his reservations when it comes to owning property:

"Covetousness, and the desire of having in our possession, and under our dominion, more than we have need of, being the root of all evil, should be early and carefully weeded out, and the contrary quality of a readiness to impart to others, implanted. This should be encourag'd by great commendation and credit, and constantly taking care that he loses nothing by his liberality." (Locke, 1996: VII.110.3)

\subsection{From Law of Nature to Natural Rights to Social Contract Theory}

Our discussion so far has led us to observe the following dynamic of reasoning in Locke:

(1) Locke's first premise (or, in this case, metaphysical presupposition) is that all of the material world (which includes all living and non-living things) has its Architect and Law-Giver in the person of an omnipotent Creator;

(2) the state of nature is governed by the law of nature that reflects the world's Architect's original creative design;

(3) through experience and the use of reason, humans are able to observe and infer the implications of the Law of Nature for human lives, both individual and social, as these implications are expressed in the intrinsic Natural Rights of all people, namely the right to life, health, liberty, and possessions;

"The state of nature has a law of nature to govern it, which obliges every one: and reason, which is that law, teaches all mankind, who will but consult it, that being all equal and independent, no one ought to harm another in his life, health, liberty, or possessions." (Locke, 2003: II.2.6)

(4) due to limitedness, imperfections, and corruptibility that are intrinsic to the process of human development, beginning in the state of nature and continuing in more complex civilizational settings, human individuals choose to live in political communities governed by a social contract, wherein they give up an independent exercise of some of their rights and freedoms in order to enhance the stability, justice, and prosperity of their communities.

Locke strives to follow the middle path between a quietist reliance on a divinely instituted order of absolute monarchs who exercise absolute power/jurisdiction over existing political communities by a divine right (a doctrine promoted by Sir Robert Filmer) and a despair-instilling recognition that "all government in the world is the product only of force and violence, and that men live together by no other rules but that of beasts, where the strongest carries it," which would only "lay a foundation for perpetual disorder and mischief, tumult, sedition, and rebellion" (Locke, 2003: II.1.4) - a view promoted by Hobbes' Leviathan (1651) (Gauthier, 1969). The guiding principle on this intellectual journey between the Scylla of the divinely instituted oppression by an absolute monarch and the Charybdis of the tyranny of a 'Leviathan' Prince is that of a reasonable recognition of the law of nature and the nature of men as free and equal agents living within the order of creation. Hence the need for men to know to whom they are to be subjected and whether this person (or institution) has the legal right to exercise power over them. In Locke's words:

"It is in vain then to talk of subjection and obedience without telling us whom we are to obey [...]; there must be ways of designing, and knowing the person to whom this regal power of right belongs; and a man can

XLinguae, Volume 14 Issue 3, June 2021, ISSN 1337-8384, eISSN 2453-711X 
never be obliged in conscience to submit to any power, unless he can be satisfied who is the person who has a right to exercise that power over him." (Locke, 2003: I.9.81)

A government can only be deemed legitimate if it emerges based on the consent of the governed. People must transfer their rights implied in the law of nature to the government in a deliberate, free manner. Such joining of a human political community is binding and permanent, requiring a universal consent of the governed. On the other hand, the ruler of the community is selected by majority consent. Such a mechanism of establishing a political community and its governance does not normatively prescribe any given form of government (whether it be a democracy, aristocracy, or monarchy). Instead, it lays the foundations of its legitimacy.

\section{Assessing Locke's Thinking on the Nature of Human Rights: Western Perspectives}

It is beyond doubt that the ideas of John Locke have greatly influenced Western political, social, as well as ethical thought. It was on the theories and principles of John Locke that modern Western liberalism evolved through the centuries. Western scholars have since long argued that his vision of political philosophy with a strong emphasis on the natural law continues to exert a strong influence on the contemporary socio-political discourse and political practice in the West. Examples of such evaluative studies can be found in Wolfgang Von Leyden's (1956) "John Locke and natural law;" or Klaus Fischer's (1975) "John Locke in the German Enlightenment: An Interpretation." As many interpreters in the West point out, Locke's importance reaches beyond the realm of political philosophy. In fact, his most extensive work “An Essay concerning Human Understanding" (1690) was devoted to epistemology and the related attempt to establish a new scientific method based on empirical observations (see especially William Uzgalis' (2019) extensive study on Locke). Uzgalis (2019) introduces Locke's view as one that showed conviction of being more scientific and producing better-established knowledge. The reason for this, according to Uzgalis, is that it is based upon induction, rather than abstract speculations (such as in metaphysics) or intellectual deduction (namely of the Aristotelian type). This emphasis on empirical proof along with Locke's preference for inductive reasoning distinguishes the English thinker as one of the founding fathers of the empirical method.

Western interpreters try to approach John Locke's corpus (that is, his entire body of writings) holistically. Besides his "Essay concerning human understanding," John Locke published his most important work on political philosophy, "Two Treatises of Government," in 1690 - these works then constitute the main body of writings that is being interpreted in the West (Tuckness, 2018). Locke's Two Treatises of Government was so innovative and revolutionary that he published it anonymously. Tuckness, Uzgalis, and others observe that this work can, to some degree, be considered Locke's commentary on the political turmoil that befell England in 1688, when William of Orange (William III) together with his wife, Queen Mary, deposed and ousted the unpopular king James II in what came to be known as the 'Glorious Revolution'. In his Two Treatises, Locke strived to justify this revolutionary turn of events as well as the rising resistance to the next king, Charles II. Tuckness (2018) further argues that Locke's treatises have also served as a major resource against and counter-argument to Thomas Hobbes' "Leviathan" (1651) - a work that, in stark contrast to Locke, argues in favor of an absolutist monarch who is seen as the only safeguard against the chaotic abuse by the people of their property and privacy, resulting in social uproar, political instability, and decrease in overall security. In the decades and centuries that followed Hobbes and Locke, these two approaches have constituted two competing approaches to the most acute challenges in political theory and philosophy. Existing political solutions tried to accommodate ideas and criticisms 
of both, as Richard Ashcraft (1991), Tomas Hauer (2016: 705-710), or Samuel Rickless (2020) rightly point out.

While contemporary political philosophers concur that the general concept of the modern liberal-democratic state is rooted in Locke's writings, there are numerous disagreements among Western scholars both in terms of how to understand Locke's original intentions and ideas, and how to critically appropriate them in the present political reality. In general, most of the contemporary researchers tend to explore the historical conditioning of Locke's theory of social contract while analyzing his main principles and his notion of natural rights in continuous attempts to shed new light on how to solve the tension between exercising one's natural rights freely and between the necessity for the sake of stability and order to submit to the rule of the sovereign. Western interpreters of John Locke's thought typically fall into two main categories (camps): the dominant, modernist-realist interpretation of Locke tends to see him as crypto-Hobbesian, whereas the so-called liberal-legalist tradition approaches Locke as one who promotes the idea that states voluntarily comply with a set of normative requirements due to the existing international law. (Smith, 2017) Locke's proposal of a constitutional government and the separation of powers is discussed and assessed in terms of their viability in contemporary national political contexts as well as the shifting of global power.

One group of scholars seems to dwell on Locke's insistence that true sovereignty belongs to the people of the state, not the state as such. Based on what Locke calls 'the law of nature,' all human beings are born with natural rights and are equal from the perspective of the law. The assumption here is that this 'law of nature' or 'natural law' is immutable and applicable in all contexts and historical/cultural circumstances. A good example here is Olkan Senemoglu (2017), who takes up the daunting task of conducting a comparative, analytical study on human nature and society, comparing the views of John Locke and Jean Jacques Rousseau. Senemoglu rightly observes that the issues of human nature and society are not philosophically 'self-serving' in either of the authors but are rather aimed at solving the problem of achieving a good government. The purpose then is to identify how our knowledge of human nature and society pertains to our human efforts to design and implement public governance, the rule of law, and order in the given society. In effect, the whole political system is derived from these two key components. The more 'anthropocentric' of the two is Rousseau. The French philosopher is not convinced that humans live in social relationships (that is, are socialized on a societal level) because of some God-given character of their human nature or their being governed by some omnipresent law of nature. (Senemoglu, 2017: 187) Humans have their needs that they wish to have fulfilled, and the processes of maturation and socialization take place as a compromise to achieve the set human goals. When the human individual reaches the so-called 'General will,' he or she harmonizes with the public authority and forsakes whatever was particular to him/her in one's natural state of things. Natural rights, therefore, are not absolutely intrinsic to human nature and can be adjusted and/or revoked for the sake of achieving concrete human goals (presumably noble human goals) of the socialized human individual living in a web of socio-political relationships.

Locke, on the other hand, insists on the intrinsic and irrevocable nature of natural rights and the legitimacy to protest or even to revolt against the government if the government violates the free exercise of these rights. While education plays an important role in this process, it has its limits and should not be thought of as an almighty tool in reshaping human nature. As Senemoglu rightly observes in his reading of Locke, the human being is a relational being; as such, the human was created as a social being who lives and thrives with others in social relationships. The society with its political structures exists in order to protect basic human rights (natural rights) pertaining to one's life, property, and liberty.

XLinguae, Volume 14 Issue 3, June 2021, ISSN 1337-8384, eISSN 2453-711X 
To be sure, Locke's idea that people are naturally, intrinsically invested with these rights was revolutionary in his time, not only in Europe but worldwide. Monarchical and tyrannical forms of government up until that time assumed that the right to govern comes from a mythological order of things when the primordial, heavenly figure exercised his/her power over the forces of chaos and instituted the earthly ruler as a reflection of this mythic celestial rule. Power was thus invested from above and imposed on those to be governed as they were the children of chaos whose propensity to chaotic behavior needed to be subdued. Senemoglu (2017), Nickel (2019), Uzgalis (2019), and Tuckness (2018) show that Locke, in contrast, comes with a novel idea of a civil state founded on the principle of protecting the people's rights and preserving their welfare. It is a 'bottom-up' approach in the theory of political power. To ensure that the power of the civil state stays limited and monitored, power must be divided into three branches that balance each other out - the legislative, judicial, and executive. This arrangement is lifted up as the best solution (under the given circumstances) for protecting people's natural rights - namely (above all) the right to life, liberty, and property. The task of the national government then is to protect the people from an outside threat, maintain stability, and social harmony through the rule of law. (Tomanek et al., 2019) Also revolutionary is Locke's idea that people, as the original bearers of natural rights, are entitled to rise up and dissolve their government if this government becomes tyrannical and ceases to act in their interest. The government's sovereignty is thus contingent upon its ability and resolve to serve the people.

While Senemoglu seems to favor Locke's approach to natural rights, seeing them as intrinsic and inalienable in their ontological character, Diana Tietjens Meyers (2016) adopts a more critical approach. Meyers wonders how we can reconcile the typical insistence on the intrinsic character of human rights as being based on the ontological fact of our being human when confronted with the actual human rights landscape of our present global world. She is also highly critical of what she perceives as Locke's canceling of the rights of criminals. (Meyers, 2016: 480-484) Tomas Hauer (2016) also offers a different reading of Locke from the one provided by Senemoglu, insisting that while Locke's predecessors typically appealed to Divine order of things (or God's intention) when explaining the existing theory of state power, Locke's revolutionary contribution consisted in his insistence that the legitimacy of state power is derived from a freely established social contract between the rulers and the ruled. Hauer overlooks Locke's emphasis on the divine origin of the law of nature and its significance for the emergence and exercise of natural rights.

A more creative approach to Locke can be seen in Brian Smith's (2017) scholarly work focused on Locke's contribution to international cooperation between political communities as well as the largely ignored emphasis in Locke that "political communities emerge out of human sociability, friendship, and trust." (Smith, 2017: 379) The role of the state then is to create a socio-political and cultural environment conducive to fostering friendship, altruism, and overall human sociability. These will, in turn, provide the much-needed social glue to human political communities.

In "The Case for an Inclusive Human Right to Property: Social Importance and Individual Self-Realization," Laura Dehaibi (2015) notices the pervasive social implications of the emergence of money as currency in the context of Locke's treatment of the subject. As the exchange of goods gives way to the emergence of a common currency in the form of money, this in turn eliminates limits on the amount of property an individual can obtain. This then becomes the root condition for unequal distribution of wealth, the creation of social classes, and the emergence of exploitation. Dehaibi explores Locke's assessment of the new solutions that this situation requires for communal living. According to Locke, people willingly give up some of their natural rights in exchange for being protected by common laws and the commonly recognized power of the sovereign to enforce those laws. Paradoxically, in order to 
secure their freedom and rights, people must give up some of their natural rights or, to put it more precisely, they must give up the spontaneous exercise of their rights in favor of the coordinated, state-guaranteed implementation of these rights. This includes their right to property, which has immense social consequences. Along with Locke, Dehaibi argues that property is not merely a tool of political and economic domination but also a means to achieve inner fulfillment and meet the needs of the community. Dehaibi's approach leads us to further reflect on the nature of the right to individual property and its social functions and responsibilities in the context of our common striving for social justice. It will yet need to be explored whether Locke's conception of natural right to property ownership can be reconciled with this more robust notion of the social importance of property and the 'positive freedom' (i.e., when ensuring subsistence, self-realization and agency) such rights can convey to humans. Sinja Graf (2018) is another promising philosopher who develops this topic. She believes that it was the introduction of money into the system of social governance that weakened or even destroyed the original relationship between the self and humanity. The resulting division of humankind into separate tribes, peoples, and nations under sovereign national governments reflects the failure of implementing the governing principles of natural law, according to Graf (2018: 560; see also Haddad, 2003 and Reno, 2009) - which is an idea that can be traced directly to Locke.

Another important aspect connected to Locke's notion of natural rights is that of human freedom. Alexey Alyushin (2017) takes up the problem of individual freedom vs. state paternalism in his study "Liberalism? Forget it" and points out that the acclaimed ideology of liberalism (or liberal democracy) is now under great pressure from the ever-rising trend of state paternalism (both in Europe and globally). After praising Locke, Kant, Mill, and others as ideological fathers of classical liberalism, Alyushin argues that "the pressure [of state paternalism] comes not only from above (that is, from authorities); the people also welcome more paternalism. They appear not to value their individual freedom and independence, and they are inclined to give them up voluntarily to some mighty organization such as the state in exchange for care, protection and leadership." (Alyushin, 2017: 375) This development seems to suggest that there is a hierarchy among the so-called 'natural rights' as these are exercised and valued by individual humans over the ages. In this hierarchy, the socalled 'social rights' (i.e., the welfare, protection, and stability provided by the state or other major political/economic entity) appear to take precedence (at least temporarily) to the fundamental political rights and freedoms.

The struggle to understand and define the 'Lockean' heritage thus necessarily includes comparisons of his thoughts to those of Karl Marx (1818-1883) and his followers. While most Western scholars of John Locke remain critical to Marxist doctrines, such as Hugh Breakey (2017), Joshua D. Glawson (2018), or Adam Mossoff (2012), others are more inclined to endorse Marx's appropriation of Locke and the transformation or critique of his ideas to serve a radically different vision of the desired socio-political system. Among these 'revisionist' scholars, Murat Birdal (2007), Laura Dehaibi (2015), Charles M. Rupert (2017), Eric Allen Engle (2008), or Jukka Gronow (2016) appear to be more prominent. Especially useful in this regard seems to be Eric Allen Engle's study on "Karl Marx's Intellectual Roots in John Locke" (Engle, 2011; originally published on Sep 15, 2008), which argues for an implicit continuity between Locke and Marx on some important issues pertaining social and political theory. Engle shows that Marx integrates the best emphases from a variety of liberal individualists, most notably those of Locke and Rousseau. Furthermore, Engle opines that Marx also seemed to have been indebted to Aristotle and Plato, the ancient Greek thinkers. Engle thus portrays Marx's ideas as a creative development of what may be considered the mainstream thinkers in Western thought, rather than their irreconcilable antithesis. Engle does not negate existing differences but attempts to

XLinguae, Volume 14 Issue 3, June 2021, ISSN 1337-8384, eISSN 2453-711X 
contextualize them in an innovative fashion, showing that these divergences do not constitute an absolute divide but rather a complex complementarity. Though this provocative thesis does not sit well with the typical western interpretations of Locke, it deserves to be taken seriously as a competing view situated in the larger sociopolitical discourse in the West.

\section{Assessing Locke's Thinking on the Nature of Human Rights: Vietnamese Perspectives}

John Locke's ideas attract considerable attention not only in Europe and other typically western contexts but also in Southeast Asia. Vietnamese scholars have recently stepped up their efforts in analyzing and interpreting Lock's philosophy, focusing especially on his epistemology and notions related to human rights. Though most studies pertaining to Locke are written in Vietnamese, the younger generation of authors starts publishing in English. Do Minh Hop, Nguyen Thanh, and Nguyen Anh Tuan (2006) offered a concise treatment of Locke's ideas in their "Outline of Western Philosophical History," while Do Minh Hop, Nguyen Thanh, Nguyen Dac Ly, and Nguyen Kim Binh (2013) published their summarizing research of Locke's thought in "General Philosophy." The approach of the said authors utilizes the historicaldescriptive approach. Emphasis is on a clear depiction of Locke's ideas' situatedness within the Western intellectual milieu as well as against the background of Locke's life and career. These studies do not offer a robust analysis of Locke's philosophy's influence on political practices in subsequent centuries; nevertheless, the authors recognize that Locke's thought "laid the foundations for a libertarian democratic state that opposed to the Military Dictatorships, Totalitarianism and Tyranny" (Do et al., 2006: 401-402) in the European civilizational space.

A popular work for those who study the history of Western philosophy in Vietnam is the "History of Philosophy" by Nguyen Huu Vui (2002). The author mentioned the thought of John Locke as inspiring within the historical flow of Western philosophy. He pointed out that Locke criticized Rene Descartes' theory of acknowledging the existence of innate thoughts by arguing its absurdity. Nguyen Huu Vui lifts up Locke's empirical method and traces its affinity to Aristotle. Among other things, Nguyen points out Locke's epistemological inconsistency, which became the subject of Berkeley's later criticism. Again, there is not treatment of Locke's notions of natural law and natural (human) rights provided by this author.

Mai Son is the next Vietnamese scholar who reflects critically on Locke's epistemology while also offering a concise summary and evaluation of Locke's political philosophy. In his "101 Philosophers," Mai Son (2007) considered John Locke to be the founder of the empirical theory, even though Francis Bacon (15611626) was the one who presented the theory first. When talking about Locke's empirical theory, Mai Son referred to Locke's "Essay Concerning Human Understanding" (1869), considering it as the first important work of empirical theory. Mai Son considers as important Locke's contention that the perceptions of humans at birth do not differ from blank papers, which gives primacy to sensual and conscious experience (i.e., experience by observation and experience by consciousness). In addition, Locke's perspective on knowledge, such as his definition of knowledge, levels of knowledge (intuitive knowledge, proving knowledge, sensory knowledge) are analyzed. Eventually, however, Mai Son arrives at the conclusion that Locke's argument was not conclusive, which is why George Berkeley (1734-1753) and Gottfried Wilhelm Leibniz (1646-1716) later rejected it.

In his treatment of Locke's political philosophy, Mai Son focused on Locke's "Two Treatises of Government." He appreciates the underlying principle of equality as well as Locke's positive view of human nature. Mai also reflects critically on the fact that the natural rights of man are not sustainable because the exercise of his rights often damages the rights of others. The solution in the form of a social contract thus seems 
feasible in an attempt to ensure that everyone can exercise their rights. Following from this line of reasoning is the idea that social contracts become foundational for any successful civil society as they enable the human political community to implement the natural rights of humans in a balanced way. Mai's work is important in the Vietnamese academic environment; nevertheless, his research does not entail a viable bridge to contemporary problems in political philosophy relative to Locke's ideas.

Another Vietnamese author who is appreciative of Locke's philosophical ideas is Nguyen Uoc who attributes 'prophetic significance' especially to Locke's empirical theory. In terms of epistemology, Nguyen Uoc thinks Descartes influenced Locke, but he also notices that Locke's conclusions differ from Descartes'. Nguyen Uoc offers a comparative analysis of Locke's epistemology to that of Bertrand Russell (1872-1970) or Immanuel Kant (1724-1804). Regarding political philosophy, Nguyen Uoc analyzes two important positions in Locke's philosophical corpus: (1) the idea of representative government and (2) that of the majority rule. Although both Hobbes and Locke saw the social contract as a tool to maintain social order, Nguyen Uoc is convinced that Locke went further. Especially disruptive is the idea by Locke that if the ruler does not bring benefits to the contractors, the people may choose another ruler. Locke's view of social contract and natural rights is seen by Nguyen Uoc as directly related to the emergence of a mature concept of Western democracy. As for educational philosophy, Nguyen Hoc lifts up Locke's belief that children are born with blank minds, which is why education should encourage experimentation and promote critical thinking in the acquisition and ordering of knowledge (on Locke's contribution to education, see also: Dinh - Doan, 2018).

An important contribution to researching Locke's philosophical legacy in Vietnam was also made by Ngo Khac Son (2017) who successfully defended his doctoral thesis "The problem of the rule of law in John Locke's thought and its current meaning". In his article "John Locke's Thoughts on Power Controlling" (2017), Ngo Khac Son analyzes Locke's idea on four basic principles to control the power of the legislature. The Government must respect the rights of people as it depends on the people for its legitimacy and sustenance. He also highly evaluates Locke's "the rights of people" principle. This principle, in Ngo Khac Son's view, constitutes "an outstanding contribution of Locke," which the government officials should pay attention to, lest they "instigate indignation among the people" (Ngo, 2017).

There are several other authors who have picked up on the importance and inspiring potential of John Locke in Vietnam, among them, Nguyen Tan Hung (2012), Dinh Ngoc Thach (2007), Nguyen Thi Thanh Huyen (2012), or Chu Van Tuan (2016), among others. While most of the attention of the said Vietnamese authors typically revolves around Locke's epistemology, ideas related to educational reform, and the role of government in civil society, attempts are made to contextually understand and sensitively interpret Locke's ideas concerning the natural law and its relevance for natural rights of humans as these become legally codified in later human rights charters. Still, more work needs to be done in this respect.

\section{Conclusion}

The task to understand John Locke's notions related to human rights and their contemporary ethical and political implications continues to be relevant in Vietnam as well as in the West. This is especially true when it comes to the question of the very 'nature' of human rights as purported by Locke. Even more difficult seems to be the continuing task to draw contemporary inspirations by philosophers and policymakers from what might be labeled as an 'outdated' metaphysical position held by Locke. Can we today still invoke the idea of humans possessing a specific, definable 'human nature'? Similarly, can we appeal to a 'natural law,' which would imply that we still

XLinguae, Volume 14 Issue 3, June 2021, ISSN 1337-8384, eISSN 2453-711X 
believe in some kind of intentional ordering of nature, intrinsic and unavoidable in character? Or is it merely a figure of speech, a helpful linguistic play on words that enables us to maintain the validity of general imperatives of civility as these have been formulated in the past three hundred years and codified in the Universal Declaration of Human Rights (1948)? If there is such a thing as 'natural law,' it wields universal authority over humanity. Transgressions against such universal authority of the natural law would constitute a 'universal crime' - i.e., a crime against all of humanity, as Locke incisively argues in his Second Treatise of Government. Hence the rising challenge that the broadly liberal European political theories must address when they deal with coercive political actions in non-European socio-political environments. (Graf, 2018) Being essentially Deist, Locke held certain presuppositions about the reality of the world, which he considered the result of an intentional, deliberate act of creation. Hence his insistence on the existence of a governing, all-pervasive natural law (or law of nature). Of course, he would not have phrased it this way but would have rather insisted that the existence of the law of nature is a logical inference based on our observation of how the world of living things operates - especially the desire/will to live on the side living things. Human rights, then, are natural expressions of the human species' will to live under the conditions of social and moral entropy. (cf. Pala, 2017)

Western scholars, in general, discuss how the concept of 'natural law' morphed into our modern conception of 'human rights' and how theories of contract (especially that of John Locke) limited the power of the monarchs, which eventually led to democracy and the rule of law as based on human dignity and inalienable freedoms. They deal with the challenges that laissez faire and individualism (thought by many to be intrinsic to liberalism) (Bahovec, 2015) pose to the current socio-political arrangements in Western countries. (Slivka, Kardis, 2018)

Also important to notice is the fact that there is a rising number of Western scholars who have recently taken an interest in analyzing and comparing John Locke and Karl Marx. This comparison is highly relevant to Vietnamese scholars who approach Locke's legacy from a different sociopolitical environment and hold different metaphysical presuppositions about reality from those of Locke or most Western scholars. Questions of epistemology and ensuing scientific method seem to be more frequent in the research papers of the current Vietnamese scholars when it comes to reflecting on Locke's philosophical legacy. However, more poignant questions of the nature of laws and human rights, the legitimacy of the government's authority in human political communities, and the relationship between freedom and duty are rising to new prominence.

\section{Acknowledgements}

This research is funded by Vietnam National Foundation for Science and Technology Development (NAFOSTED) under grant number 603.01-2020.300

\section{Bibliographic references}

ALYUSHIN, A. 2017. Liberalism? Forget it! In: Axiomathes, vol. 27, n. 4, pp. 375391.

BAHOVEC, I. 2015. Christianity in confrontation with individualism and crisis of western culture: person, community, dialog, reflexivity, and relationship ethics. In: Bogoslovni Vestnik, vol. 75, n. 2, pp. 335-346.

BIRDAL, M. 2007. Locke's Theory of Property and Its Marxist Critique: Locke and Marx on Property Rights and Individual Liberties. In: İktisat Fakültesi Mecmuası, vol. 57, n. 1, pp. 39-61.

BREAKEY, H. 2017. Arbitrary Power, Arbitrary Interference and the Abuse of Power: Corruption, Natural Rights and Human Rights. In: Savur, S. and S. Sandhu (eds.), 
Responsible Leadership and Ethical Decision-Making. Bingley, UK: Emerald Publishing Limited, pp. 125-145.

CHU, V.T. 2016. The Western philosophers' viewpoint on freedom and the law. In: Vietnam Social Science Review, n. 9, pp. 36-42.

CUTTICA, C. 2016. Sir Robert Filmer (1588-1653) and the patriotic monarch: Patriarchalism in seventeenth-century political thought. Manchester: Manchester University Press.

DALY, J. 2017. Sir Robert Filmer and English Political Thought. Toronto: University of Toronto Press.

DE MONTESQUIEU, B. 1900. The spirit of laws. Nugent, T. (transl.). London: Colonial Press.

DEHAIBI, L. 2015. The Case for an Inclusive Human Right to Property: Social Importance and Individual Self-Realization. In: Western Journal of Legal Studies, vol. 6, n. 1, Available online: http://ir.lib.uwo.ca/uwojls/vol6/iss1/5.

DINH, N.T. 2007. The political philosophy of John Locke: The nature and significance of history. In: Review of Philosophy, n. 1(188), pp. 37-43.

DO, M.H. - NGUYEN, T. - NGUYEN, A.T. 2006. Outline of Western Philosophical History. Ho Chi Minh City: Ho Chi Minh City General Publishing House.

DO, M.H. - NGUYEN, T. - NGUYEN, D.L. - NGUYEN, K.B. 2013. General Philosophy. Hanoi: Era Publishing House.

DO, T.K.H. 2017. Human rights in J.Locke's thoughts on State. In: Review of Philosophy, n. 5(312), pp. 56-63.

DUNN. J. 2003. Measuring Locke's Shadow. In: I. Shapiro (ed.), Two Treatises of Government and A Letter Concerning Toleration. New Haven - London: Yale University Press, pp. 257-285.

ENGLE, E.A. 2011. Karl Marx's Intellectual Roots in John Locke (September 15, 2008). In: Postmodern Openings, vol. 7, n. 1, pp. 29-37 Available online: https://ssrn.com/abstract=1268545.

FISCHER, K.P. 1975. John Locke in the German Enlightenment: An Interpretation. In: Journal of the History of Ideas, vol. 36, n. 3, pp. 431-446.

GAUTHIER, D.P. 1969. The logic of Leviathan: the moral and political theory of Thomas Hobbes. Oxford: Oxford University Press.

GLAWSON, J.D. 2018. Labor and Property: Locke vs Marx. In: Medium.com Available online: https://medium.com/@JoshuaGlawson/labor-and-property-locke-vsmarx-b1b79f34193b

GRAF, S. 2018. 'A Trespass against the Whole Species': Universal Crime and Sovereign Founding in John Locke's Second Treatise of Government. In: Political Theory, vol. 46, n. 4, pp. 560-585. DOI: 10.1177/0090591717752468.

GRANT, R.W. 2003. John Locke on Women and Family. In: I. Shapiro (ed.), Two Treatises of Government and A Letter Concerning Toleration. New Haven - London: Yale University Press, pp. 286-308.

GRONOW, J. 2016. John Locke, Adam Smith and Karl Marx's Critique of Private Property. In: On the Formation of Marxism: Karl Kautsky's Theory of Capitalism, the Marxism of the Second International and Karl Marx's Critique of Political Economy. Leiden - Boston: Brill, pp. 225-251.

HADDAD, B. 2003. Property rights, ecosystem management, and John Locke's labor theory of ownership. In: Ecological Economics, vol. 46, n. 1, pp. 19-31.

HARRISON, R. 2003. Hobbes, Locke, and confusion's masterpiece: an examination of seventeenth-century political philosophy. Cambridge - New York: Cambridge University Press.

HAUER, T. 2016. John Locke and the nature of modern democracy. In: Anthropology, archeology, history \& philosophy conference proceedings, vol II. International

XLinguae, Volume 14 Issue 3, June 2021, ISSN 1337-8384, eISSN 2453-711X 
Multidisciplinary Scientific Conferences on Social Sciences and Arts. Albeny, Bulgaria: SGEM, pp. 705-710.

LOCKE, J. 1975. An Essay Concerning Human Understanding. In: P. H. Nidditch (ed.), The Clarendon Edition of the Works of John Locke. Oxford: Clarendon Press. doi:10.1093/actrade/9780198243861.book.1/actrade-9780198243861-book-1.

LOCKE, J. 1989. Some Thoughts Concerning Education. John W. Yolton - Jean S. Yolton (eds.). Oxford: Clarendon Press. doi:10.1093/actrade/9780198245827.book.1/actrade-9780198245827-book-1

LOCKE, J. 1996. Some Thoughts Concerning Education; and The Conduct of the Understanding. R.W. Grant - N. Tarcov (eds.). Indianapolis: Hackett Publishing Co.

LOCKE, J. 2003. Two Treatises of Government and A Letter Concerning Toleration.

I. Shapiro (ed.). New Haven - London: Yale University Press.

LOCKE, J. 2006. An Essay Concerning Toleration: And Other Writings on Law and Politics, 1667-1683: And Other Writings on Law and Politics, 1667-1683. In: J. R. Milton and Philip Milton (eds.), The Clarendon Edition of the Works of John Locke: An Essay Concerning Human Understanding. Oxford: Clarendon Press. doi:10.1093/actrade/9780199575732.book.1/actrade-9780199575732-book-1

MAI, S. 2007. 101 Philosopher. Hanoi: Knowledge Publishing House.

MEYERS, D.T. 2016. Recovering the Human in Human Rights. In: Law Culture and the Humanities, vol. 12, n. 3, pp. 474-484. DOI: 10.1177/1743872114528440.

MOSELEY, A. 2005. John Locke's Morality of War. In: Journal of Military Ethics, vol. 4, n. 2, pp. 119-128.

MOSSOFF, A. 2012. Saving Locke from Marx: The labor theory of value in intellectual property theory. In: Social Philosophy and Policy, vol. 29, n. 2, pp. 283317.

NGO, K.S. 2017. John Locke's Thoughts on Power Controlling. In: Political Theory Journal, Published on 23 March 2017. Available online: http://lyluanchinhtri.vn/home/index.php/dien-dan/item/1936-tu-tuong-cua-john-lockeve-kiem-soat-quyen-luc.html

NGUYEN, H.V. 2002. History of Philosophy. Hanoi: National Political Publishing House.

NGUYEN, T.H. 2012. History of Western Philosophy - From Ancient Greek philosophy to German classical philosophy. Hanoi: Truth-National Political Publishing House.

NGUYEN, T.T.H. 2012. John Locke's thought on Property in the Second treatise on the government. In: Journal of Science - VNU HN, Social Sciences and Humanities, vol. 28, n. 1 , pp. 166-172.

NGUYEN, U. 2012. Outline of Western Philosophy. Hanoi: Knowledge Publishing House.

NICKEL, N. 2019. Human Rights. In: Edward N. Zalta (ed.), The Stanford Encyclopedia of Philosophy (Summer 2019 Edition). Available online: https://plato.stanford.edu/archives/sum2019/entries/rights-human/.

PALA, G. 2017. The theological view of social work a contribution to the social science vs. Religion debate. In: European Journal of Science and Theology, vol. 13, 3, pp. 35-45.

RENO, J. 2009. Private Property and the Law of Nature in Locke's Two Treatises The Best Advantage of Life and Convenience. In: American Journal of Economics and Sociology, vol. 68, n. 3, pp. 639-663.

RICKLESS, S. 2020. Locke On Freedom. In: Edward N. Zalta (ed.), The Stanford Encyclopedia of Philosophy (Spring 2020 Edition). Available online: https://plato.stanford.edu/archives/spr2020/entries/locke-freedom/

RUPERT, C.M. 2017. Locke, Marx, and Two Theories of Labor. A philosophical Essay on how to fix our political economy. [online]. In: Next system project national 
essay competition, 2017 Available online: https://thenextsystem.org/sites/default/files/2017-07/Rupert_GraduateFirst.pdf

SCHOCHET, G.J. 1967. Thomas Hobbes on the Family and the State of Nature. In: Political Science Quarterly, vol. 82, n. 3, pp. 427-445.

SENEMOGLU, O. 2017. Human Nature and Society in the Philosophy of John Locke and Jean Jacques Rousseau. In: Insan \& Toplum, the Journal of Humanity \& Society, vol. 7, n. 1, pp. 187-221. DOI: 10.12658/human.society.7.13.M0183.

SHAPIRO, I. 2003. John Locke's Democratic Theory. In: I. Shapiro (ed.), Two Treatises of Government and A Letter Concerning Toleration. New Haven - London: Yale University Press, pp. 309-340.

SLIVKA, D. - KARDIS, K. 2018. Examining the Interplay of Church and Family in Cultivating the Faith in Teenagers: Towards a New Strategy. In: European Journal of Science and Theology, vol. 14, n. 3, pp. 53-62.

SMITH, B. 2017. Friends in the State of Nature: John Locke and the Formation of Security Communities. In: POLITY, vol. 49, n. 3, pp. 379-407. DOI: 10.1086/692294. TOMANEK, P. - VALCOVA, K. - PALA, G. - KRYUKOVA, N.I. - VASBIEVA, D.G. 2019. Abortion and euthanasia as threats to traditional family a comparative case study on Slovakia and the Russian Federation. In: European Journal of Science and Theology, vol. 15, n. 6, pp. 61-73.

TUCKNESS, A. 2018. Locke's Political Philosophy. In: Edward N. Zalta (ed.), The Stanford Encyclopedia of Philosophy (Summer 2018 Edition). Available online: https://plato.stanford.edu/archives/sum2018/entries/locke-political/

TULLY, J. 1982. A discourse on property: John Locke and his adversaries. London New Yor: Cambridge University Press.

UNITED NATIONS. 1948. Universal Declaration of Human Rights. [online]. Paris: UN Publishing. Available online: https://www.un.org/en/about-us/universaldeclaration-of-human-rights.

UZGALIS, W. 2019. John Locke. In: Edward N. Zalta (ed.), The Stanford Encyclopedia of Philosophy (Spring 2019 Edition) Available online: https://plato.stanford.edu/archives/spr2019/entries/locke/

VON LEYDEN, W. 1956. John Locke and natural law. In: Philosophy, vol. 31, n. 116, pp. 23-35.

Words: 8893

Characters: 58167 (32,32 standard pages)

Dr. Hoa Thi Kim Do, PhD.

Institute of Philosophy

Vietnam Academy of Social Sciences

59 Langha, Badinh, Hanoi

Vietnam

hoatuanphuc@gmail.com

prof. PhDr. Michal Valco, PhD.

Evangelical Lutheran Theological Faculty

Comenius University in Bratislava

Bartokova 8

81102 Bratislava

Slovak Republic

michal.valco@uniba.sk

XLinguae, Volume 14 Issue 3, June 2021, ISSN 1337-8384, eISSN 2453-711X 
Kazan Federal University

Institute of Psychology and Education

Kremlyovskaya Str. 18

RU - 420008 Kazan

Russian Federation 